\title{
Removal of the periplasmic DNase before electroporation enhances efficiency of transformation in the marine bacterium Vibrio alginolyticus
}

\author{
Ikuro Kawagishi, Isao Okunishi, Michio Homma and Yasuo Imae†
}

Author for correspondence: Ikuro Kawagishi. Tel: +81 52 789-2993. Fax: +81 52 789-3001.

Department of Molecular Biology, Faculty of Science, Nagoya University, Chikusaku, Nagoya 464-01, Japan

\begin{abstract}
We have established a reliable procedure for electroporation in the marine bacterium Vibrio alginolyticus. Plasmids carrying the P15A replicon were found to be stably maintained in the Vibrio cells, and chloramphenicol, kanamycin or tetracycline were used for selection. Since we found that the Vibrio cells excrete DNase into the culture medium, cells were subjected to osmotic shock before extensive washing in order to remove the DNase from the periplasmic space. This manipulation resulted in about a 10-fold increase in the efficiency of transformation. In addition, cells were washed in the presence of 5-10 $\mathrm{mM}$ $\mathrm{Mg}^{2+}$ in order to stabilize the outer membrane. The efficiency of transformation was found to be optimal when cells were harvested at early stationary phase, and when electroporation was carried out at an electric field strength between 5.0 and $7.5 \mathrm{kV} \mathrm{cm}^{-1}$. Under optimal conditions, about $10^{5}$ transformants per $\mu \mathrm{g}$ of input DNA were reproducibly obtained, which is tolerable for cloning.
\end{abstract}

Keywords: Vibrio alginolyticus, transformation, electroporation, osmotic shock

\section{INTRODUCTION}

Vibrio alginolyticus and the closely related species $V$. parahaemolyticus are slightly halophilic Gram-negative bacteria mainly found in estuarine or coastal areas (Kaneko \& Colwell, 1973). In seawater, the cell is rodshaped and propelled by a single polar sheathed flagellum. When the cell attaches to an animate or inanimate surface, it differentiates into a multinucleate and highly elongated cell, which migrates over viscous surfaces by numerous unsheathed lateral flagella (Allen \& Baumann, 1971; Shinoda \& Okamoto, 1977; McCarter \& Silverman, 1990).

Recently, Atsumi et al. (1992) found that the polar flagellar motor is driven by sodium-motive force across the cytoplasmic membrane, whereas the lateral flagellar motor is driven by proton-motive force. A single cell possessing two types of motors with two different coupling ions provides an excellent experimental system for studying

†Professor Yasuo Imae, who had devoted himself to studying various aspects of bacterial motility and behaviour, died suddenly of a cerebral haemorrhage at the age of 53 during this work. This article is dedicated to him by the rest of authors with deep sorrow, professional respect, and personal affection. the bioenergetics of bacterial flagellar motors. These organisms are also intriguing in the following respects: (i) increase in viscosity is the signal for induction of the lateral flagellar genes (Belas et al., 1986) and the polar flagellum is proposed to function as the viscosity sensor (McCarter et al., 1988; McCarter \& Silverman, 1990); (ii) they have a respiration-coupled primary sodium pump, NADH:quinone oxidoreductase (Tokuda \& Unemoto, 1982; Tsuchiya \& Shinoda, 1985); (iii) when swarming, they migrate as tufts of elongated cells (Henrichsen, 1972; McCarter \& Silverman, 1990; Allison \& Hughes, 1991); (iv) in the marine ecosystem, they are major decomposers of chitin, a ubiquitous form of marine biomass ( $Y u$ et al., 1991).

In order to investigate any of the aspects described above, it is vital to analyse the genes involved. Transposon insertion mutagenesis has been carried out in $V$.parabaemolyticus and other marine Vibrio spp. (Belas et al., 1984, 1986; McCarter \& Silverman, 1987; McCarter et al., 1988) and the genes of interest have been cloned into Escherichia coli using the inserted transposons as markers. In addition, triparental mating has been used to disrupt a gene on the $V$. parabaemolyticus chromosome (McCarter $e t$ al., 1988). Furthermore, two generalized transducing 
phages in $V$. parabaemolyticus and $V$. alginolyticus have been isolated and characterized (Muramatsu \& Matsumoto, 1991).

It is also important to establish a host-vector system and an efficient transformation procedure in marine Viibrio spp., since a gene of interest can then be cloned by complementation and analysed in the Vibrio cells. Hamashima et al. (1990) reported that using electroporation, several strains of $V$. alginolyticus and $V$. parabaemolyticus could be transformed with the E. coli plasmids pACYC184, pBR322 and pHSG398 (a pUC-type plasmid with the pMB1 replicon and the chloramphenicol resistance gene). The efficiency of transformation, however, was too low (about $10^{2}$ transformants per $\mu \mathrm{g}$ DNA) for routine use.

In this paper, we report that the removal of DNase from the periplasmic space by osmotic shock and washing the cells in the presence of $\mathrm{Mg}^{2+}$ results in reasonably efficient transformation.

\section{METHODS}

Bacterial strains. $V$. alginolyticus strain VIK2, which was used as the standard recipient for electroporation, is a rifampicinresistant derivative of the wild-type strain 138-2 (Tokuda et al., 1981). E. coli strain DH5 (Grant et al., 1990) was used as the host for isolation and construction of plasmids and as a control in the DNase test.

Plasmids. The P15A plasmids used in this study were: pACYC184 (Chang \& Cohen, 1978) with chloramphenicol resistance $\left(\mathrm{Cm}^{r}\right)$ and tetracycline resistance $\left(\mathrm{Tc}^{r}\right)$ genes; pSU18 and pSU21 (Bartolomé et al., 1991), both of which have the $\mathrm{Cm}^{r}$ gene and the $5^{\prime}$ part of the lac $Z$ gene; and pSU38 and pSU41 (Bartolomé et al., 1991), both of which have the kanamycin resistance $\left(\mathrm{Km}^{\mathrm{r}}\right)$ gene and the $5^{\prime}$ part of the lac $Z$ gene. The pMB1 plasmids used in this study were: pBR322 (Bolivar et al., 1977) with the ampicillin resistance $\left(A p^{r}\right)$ and $T^{r}{ }^{r}$ genes; $p U K 21$ (Vieira \& Messing, 1991) with the $\mathrm{Km}^{r}$ gene and the $5^{\prime}$ part of the lac $Z$ gene; pUC4K (Vieira \& Messing, 1982) with the Ap ${ }^{r}$ and $\mathrm{Km}^{\prime}$ genes; and pHSG398 (Takeshita et al., 1987) with the $\mathrm{Cm}^{\mathrm{r}}$ gene and the $5^{\prime}$ part of the lac $Z$ gene.

Media and conditions of culture. ${ }^{\prime}$. alginolyticus cells were cultured at $30{ }^{\circ} \mathrm{C}$ in complex medium $(0.5 \%$ polypeptone, $0.5 \%$ yeast extract, $0.4 \% \quad \mathrm{~K}_{2} \mathrm{HPO}_{4}, 3 \% \mathrm{NaCl}$; Tokuda, 1986) supplemented with $0.2 \%$ glucose (named VC medium). When necessary, chloramphenicol, kanamycin, rifampicin and tetracycline were added at final concentrations of $1 \cdot 25,100,50$ and $1.25 \mu \mathrm{g} \mathrm{ml} \mathrm{m}^{-1}$, respectively. E. coli cells were cultured in LB medium ( $1 \%$ tryptone, $0.5 \%$ yeast extract, $0.5 \% \mathrm{NaCl}$; Silhavy it al., 1984). For E. coli, antibiotics were used at the following concentrations $\left(\mu \mathrm{g} \mathrm{ml}^{-1}\right)$ : ampicillin, 50 ; chloramphenicol, 25; kanamycin, 50; and tetracycline, 10.

To examine whether DNase was secreted, cells were grown on DNase Test Agar (Difco), supplemented with $0.4 \mathrm{M} \mathrm{NaCl}$ for $V$. alginolyticus, and $0.1 \mathrm{M} \mathrm{HCl}$ was poured to precipitate unhydrolysed DNA.

Standard method of preparation of cells for electroporation in E. coli. Electroporation in E. coli was carried out according to Dower et al. (1988), as follows. Cells were grown in 1 litre of LB medium at $37^{\circ} \mathrm{C}$ with vigorous shaking to an $\mathrm{OD}_{600}$ of $0 \cdot 5-0 \cdot 8$. Then the cells were chilled and harvested by centrifugation $(4000 \mathrm{~g})$ for $15 \mathrm{~min}$ at $0^{\circ} \mathrm{C}$. The pellets were rinsed first with 1 litre ice-cold water, then with $20 \mathrm{ml}$ ice-cold $10 \%$ (w/v) glycerol, and the cells were resuspended to a final volume of $2-3 \mathrm{ml}$ in ice-cold $10 \%(\mathrm{w} / \mathrm{v}$ ) glycerol. A $40 \mu \mathrm{l}$ sample of the cell suspension was used in one electroporation.

Electroporation in $\boldsymbol{V}$. alginolyticus. The 'Gene Pulser' electroporation apparatus (Japan Bio-Rad Laboratories, Tokyo) was used throughout this study. The electric field strength was varied between 2.5 and $12.5 \mathrm{kV} \mathrm{cm}^{-1}$. Capacitance and resistance were fixed at $25 \mu \mathrm{F}$ and $200 \Omega$, respectively, and cuvettes with a $0.2 \mathrm{~cm}$ electrode gap were used. The bacteria were grown with shaking in $20 \mathrm{ml} \mathrm{VC} \mathrm{medium} \mathrm{at} 30^{\circ} \mathrm{C}$ to late-exponential phase, and harvested by centrifugation $(5000 \mathrm{~g}$ ) for $5 \mathrm{~min}$ at room temperature. The pellet was chilled, and washed twice with $10 \mathrm{ml}$ ice-cold $10 \mathrm{mM} \mathrm{MgSO}_{4}$ and once with $5 \mathrm{ml}$ ice-cold $10 \%$ glycerol containing $5 \mathrm{mM} \mathrm{MgSO}$. The pellet was suspended in $120 \mu \mathrm{l}$ ice-cold $10 \%$ glycerol, and used immediately for electroporation or kept frozen at $-80^{\circ} \mathrm{C}$. Forty microlitres of the cell suspension, kept at $0{ }^{\circ} \mathrm{C}$, was mixed with an appropriate amount (typically $0.1 \mu \mathrm{g}$ ) of plasmid DNA and was subjected to electroporation in a chilled cuvette. Immediately after electroporation, $1 \mathrm{ml} \mathrm{VC}$ medium was added and the cell suspension was transferred to a test tube and then incubated at $30^{\circ} \mathrm{C}$ for 50 min with shaking. The cells were precipitated, resuspended in an appropriate volume of VC medium, and plated on a selection plate. The plate was then incubated at $30^{\circ} \mathrm{C}$ overnight.

Transformation by the osmotic shock method. The procedure of osmotic shock for $V$. alginolyticus cells was modified from the method of Neu \& Heppel (1965) for E. coli cells. The cells were cultured in $20 \mathrm{ml} \mathrm{VC} \mathrm{medium,} \mathrm{harvested} \mathrm{and} \mathrm{washed} \mathrm{with} \mathrm{an}$ equal volume of motility medium $[50 \mathrm{mM}$ HEPES/Tris (pH 7.0), $0.4 \mathrm{M} \mathrm{NaCl}, 10 \mathrm{mM} \mathrm{MgSO}, 5 \mathrm{mM}$ glucose]. The pellet was resuspended in $10 \mathrm{ml} \mathrm{SNT}$ medium $[30 \mathrm{mM}$ Tris $/ \mathrm{HCl}$ (pH 8.0), $20 \%$ sucrose, $0.4 \mathrm{M} \mathrm{NaCl}$, to which EDTA was added (final $1 \mathrm{mM}$ ). The cell suspension was then incubated for $10 \mathrm{~min}$ at $30^{\circ} \mathrm{C}$ with gentle shaking. The cells were precipitated and resuspended in $10 \mathrm{ml}$ ice-cold $10 \mathrm{mM} \mathrm{MgSO}_{4}$. After incubation on ice for $10 \mathrm{~min}$, the cells were precipitated and washed as described in the previous section.

\section{RESULTS}

\section{Electroporation in V. alginolyticus}

To determine which antibiotics could be used for selection, we examined the effects of various concentrations of ampicillin, chloramphenicol, kanamycin and tetracycline on the growth of $V$. alginolyticus strain 138-2 and its rifampicin-resistant derivative VIK2. Two microlitres of overnight culture was spotted on VC plates containing various concentrations of one of the antibiotics and the plates were incubated at $30^{\circ} \mathrm{C}$. Growth of both the strains was inhibited by $1.0 \mu \mathrm{g}$ chloramphenicol ml ${ }^{-1}$, $100 \mu \mathrm{g} \mathrm{kanamycin} \mathrm{ml}^{-1}$, and $0.5 \mu \mathrm{g}$ tetracycline $\mathrm{ml}^{-1}$. In the case of kanamycin, however, spontaneous resistant colonies appeared even at $200 \mu \mathrm{g} \mathrm{ml}^{-1}$. Ampicillin, even at $1 \mathrm{mg} \mathrm{ml}^{-1}$, did not inhibit colony formation. We therefore used genes responsible for resistance to chloramphenicol $\left(\mathrm{Cm}^{\mathrm{r}}\right)$, kanamycin $\left(\mathrm{Km}^{\mathrm{r}}\right)$, or tetracycline $\left(\mathrm{Tc}^{\mathrm{r}}\right)$ as selective markers.

We first applied the standard electroporation procedure for E. coli (see Methods) to $V$. alginolyticus. Transformation of 138-2 and VIK2 cells with plasmids pACYC184, pSU18, pSU21, pSU38, pSU41, pBR322, pUK21, pUC4K and pHSG398 was attempted using chloramphenicol, 
tetracyline or kanamycin at concentrations of $1 \cdot 25,1 \cdot 25$ or $100 \mu \mathrm{g} \mathrm{ml} \mathrm{m}^{-1}$, respectively. No transformants were found with any of these combinations of host strains and plasmids, and so we explored various other conditions for the electroporation protocol.

When cells were harvested at late-exponential phase rather than carly-exponential phase and the wash media included $10 \mathrm{m.M} \mathrm{MgSO}$, we obtained tens to hundreds of transformants of $138-2$ or VIK2 with pSU21 (containing the $\mathrm{P} 15 \mathrm{~A}$ replicon and $\mathrm{Cm}^{\mathrm{r}}$ gene) in one electroporation. That the plasmid was maintained in the host cells in the original form was verified by extracting the plasmid DNA and analysing the restriction enzyme digestion pattern by agarose gel electrophoresis (data not shown). Furthermore, even in the absence of chloramphenicol, VIK2 retained the plasmid as stably as E. coli strain DH5 $\alpha$ did for at least seven generations (data not shown).

We alio obtained $\mathrm{Cm}^{\mathbf{r}}$ colonies when pHSG398 (which has the replicon of pMB1) was used. The subsequent restriction analysis, however, revealed that some kind of rearrangement had occurred. Selections using kanamycin were unsuccessful at this stage since none of the $\mathrm{Km}^{\mathrm{r}}$ colonies contained plasmid DNA. The other plasmids with the P15A replicon and $\mathrm{Cm}^{\mathrm{r}}$ gene also gave transformants, suggesting that the $\mathrm{P} 15 \mathrm{~A}$ replicon functions in the $V$. alginolyticus cell. Strains $138-2$ and VIK2 exhibited similar efficiencies of transformation.

We the refore used VIK2 as the standard host and pSU21 as the standard vector in the subsequent experiments. To avoid digestion by Vibrio restriction systems, plasmid DNA was extracted from VIK2 cells carrying pSU21 obtained in the previous electroporation experiment and used in the subsequent experiments.

\section{Effects of electric field strength, amount of plasmid DNA, and cell growth phase on the efficiency of transformation}

First, the electric field strength of the pulse upon electropuration was varied from 2.5 to $12.5 \mathrm{kV} \mathrm{cm}^{-1}$. As shown in Fig. 1, the efficiency of transformation was optimal when the electric field strength was set between $5 \cdot 0$ and $10 \cdot 0 \mathrm{kV} \mathrm{cm}^{-1}$.

Second, with the electric field strength fixed at $5.0 \mathrm{kV} \mathrm{cm}^{-1}$, the amount of plasmid DNA was varied. As shown in Fig. 2, the number of transformants increased with increasing amount of pSU21 DNA, whereas the number of transformants per $\mu \mathrm{g}$ was not much changed (maximal when $0 \cdot 1 \mu \mathrm{g}$ of DNA was applied).

Third, the growth phase at which cells were harvested was varied. Cells were harvested when the Klett value at $660 \mathrm{~nm}$ reached 50, 150 and 300 and when cultivation lasted for 5,7 and $9 \mathrm{~h}$. Volumes of culture harvested were varied, so that the total cell numbers were similar in all sampling: e.g. $60 \mathrm{ml}$ of the culture at Klett value 50 was harvested, whereas at Klett value 150 , only $20 \mathrm{ml}$ was collected. These cells were precipitated and washed as described in Methods, and electroporation was carried out with $1 \cdot 1 \mu \mathrm{g}$ pSU21 DNA and an electric field strength

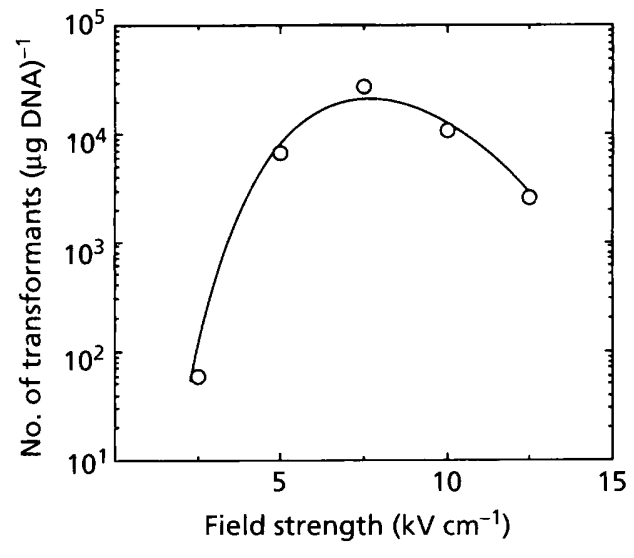

Fig. 1. Effect of electric field strength on the efficiency of transformation when electroporating $V$. alginolyticus strain VIK2. A $0.1 \mu \mathrm{g}$ sample of plasmid pSU21 DNA was added to $40 \mu \mathrm{l}$ of a suspension of VIK2 cells harvested when the Klett value (at $660 \mathrm{~nm}$ ) reached 150 .

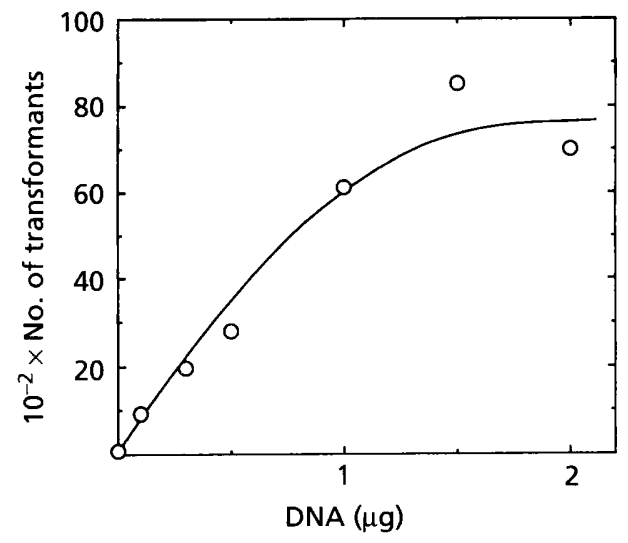

Fig. 2. Effect of the amount of DNA on the efficiency of transformation when electroporating $V$. alginolyticus strain VIK2. The electric field strength was set at $5.0 \mathrm{kV} \mathrm{cm}^{-1}$ and the other conditions were the same as Fig. 1.

of $7.5 \mathrm{kV} \mathrm{cm}{ }^{-1}$. We repeated this experiment several times and a typical result is presented in Fig. 3. The highest efficiency of transformation was obtained when the cells were harvested at early stationary phase.

\section{V. alginolyticus secretes DNase to the culture medium}

It has been reported that $V$. cholerae cells secrete DNases (Newland et al., 1985; Focareta \& Manning, 1987; Marcus et al., 1990). So we examined whether this is also the case in $V$. alginolyticus. An overnight culture of VIK 2 cells was streaked on a DNase Test Agar plate supplemented with $0.4 \mathrm{M} \mathrm{NaCl}$ and the plate was incubated at $30^{\circ} \mathrm{C}$. After overnight incubation, $10 \mathrm{ml} 1 \mathrm{M} \mathrm{HCl}$ was poured onto the plate in order to precipitate unhydrolysed DNA. As shown in Fig. 4(a), a large zone of clearing around the 


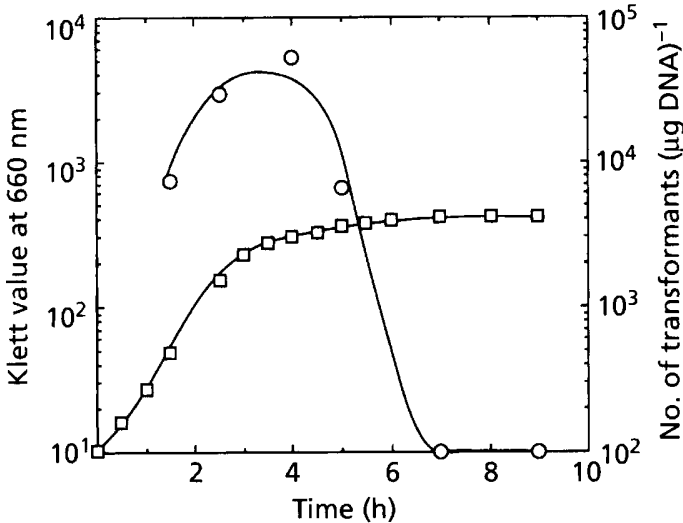

Fig. 3. Effect of the growth phase at which the cells were harvested on the efficiency of transformation when electroporating $V$. alginolyticus strain VIK2. Electroporation was carried out with $0.1 \mu \mathrm{g}$ pSU21 DNA and an electric field strength of $7.5 \mathrm{kV} \mathrm{cm}^{-1} . \square$, Klett value $(660 \mathrm{~nm})$ of the culture; $\mathrm{O}$. number of $\mathrm{Cm}^{r}$ transformants per $\mu \mathrm{g}$ DNA.
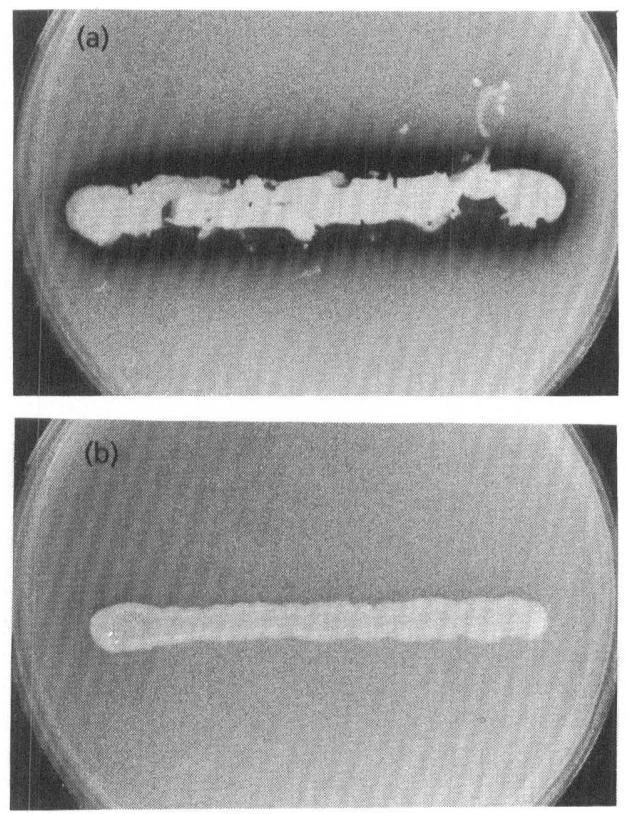

Fig. 4. Secretion of DNase by V. alginolyticus strain VIK2 (a) but not by $E$. coli strain $\mathrm{DH} 5 \alpha$ (b). Cells were grown on DNase Test Agar, supplemented with $0.4 \mathrm{M} \mathrm{NaCl}$ in the case of $\mathrm{V}$. alginolyticus. After overnight incubation at $30^{\circ} \mathrm{C}$, the DNase activity was detected by precipitating the unhydrolysed DNA with $1 \mathrm{M} \mathrm{HCl}$.

lawn of VIK2 cells was observed, indicating that DNase is indeed secreted. A similar result was obtained for the wild-type strain 138-2 (data not shown). On the other hand, the lawn of E. coli DH5 $\alpha$ cells was not surrounded by such a clearing zone (Fig. 4b).

We then examined whether covalently closed circular plasmid DNA is degraded by the secreted Vibrio DNase. Plasmid pSU21 DNA was mixed with the supernatants of

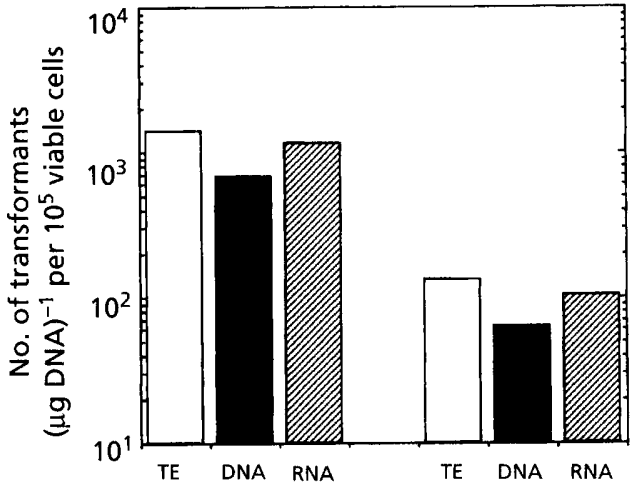

(a)

(b)

Fig. 5. Effect of osmotic shock treatment before electroporation and the presence of carrier DNA or RNA during electroporation on the efficiency of transformation. Electroporation using osmotically shocked (a) or unshocked (b) VIK2 cells was carried out in the absence (TE) or presence of $1 \mu \mathrm{g}$ of chromosomal DNA extracted from $V$. alginolyticus (DNA) or $25 \mu \mathrm{g}$ of tRNA ${ }^{\text {Phe }}$ from $S$. cerevisiae (RNA). The electric field strength was set at $7.5 \mathrm{kV} \mathrm{cm}^{-1}$ and $0.5 \mu \mathrm{g}$ pSU21 DNA was used.

cultures (Klett values about 150 ) of $138-2$, VIK2 and $\mathrm{DH} 5 \alpha$ at either $37^{\circ} \mathrm{C}$ or $0^{\circ} \mathrm{C}$. The resultant DNA was precipitated with $70 \%$ ethanol and analysed by agarose gel electrophoresis (data not shown). Significant degradation of the plasmid DNA was detected even at $0{ }^{\circ} \mathrm{C}$ when incubated with the supernatants of the 138-2 and VIK 2 cultures. The supernatant of the DH $5 \alpha$ culture, however, showed no degrading activity. We therefore suspect that by the procedure described in the previous section DNase may not be washed out from the periplasmic space and/or the outer membrane and that this may cause the low efficiency of transformation in $V$. alginolyticus.

\section{Osmotic shock before electroporation significantly improves efficiency of transformation}

Degradation of plasmid DNA might be avoided or reduced by removal of DNase from the periplasmic space and/or by adding carrier DNA or RNA. Cells were thus subjected to osmotic shock before electroporation as described in Methods. Electroporation using shocked or unshocked cells was carried out in the presence or absence of $1 \mu \mathrm{g}$ chromosomal DNA extracted from $V$. alginolyticus 138-2 or $25 \mu \mathrm{g}$ of tRNA ${ }^{\text {Phe }}$ from Saccharomyces cerevisiae (Boehringer Mannheim Yamanouchi, Tokyo). As shown in Fig. 5, the osmotic shock treatment resulted in a 10 -fold increase in the efficiency of transformation. This suggests that DNase is effectively removed from the periplasmic space of the cell. Addition of carrier DNA or RNA, however, showed no effect on the transformation efficiency of either shocked or unshocked cells (Fig. 5).

Using osmotic shock before electroporation, the effects of electric field strength, amount of plasmid DNA, and growth phase at which cells were harvested were examined again. As shown in Fig. 6, the tendencies were 

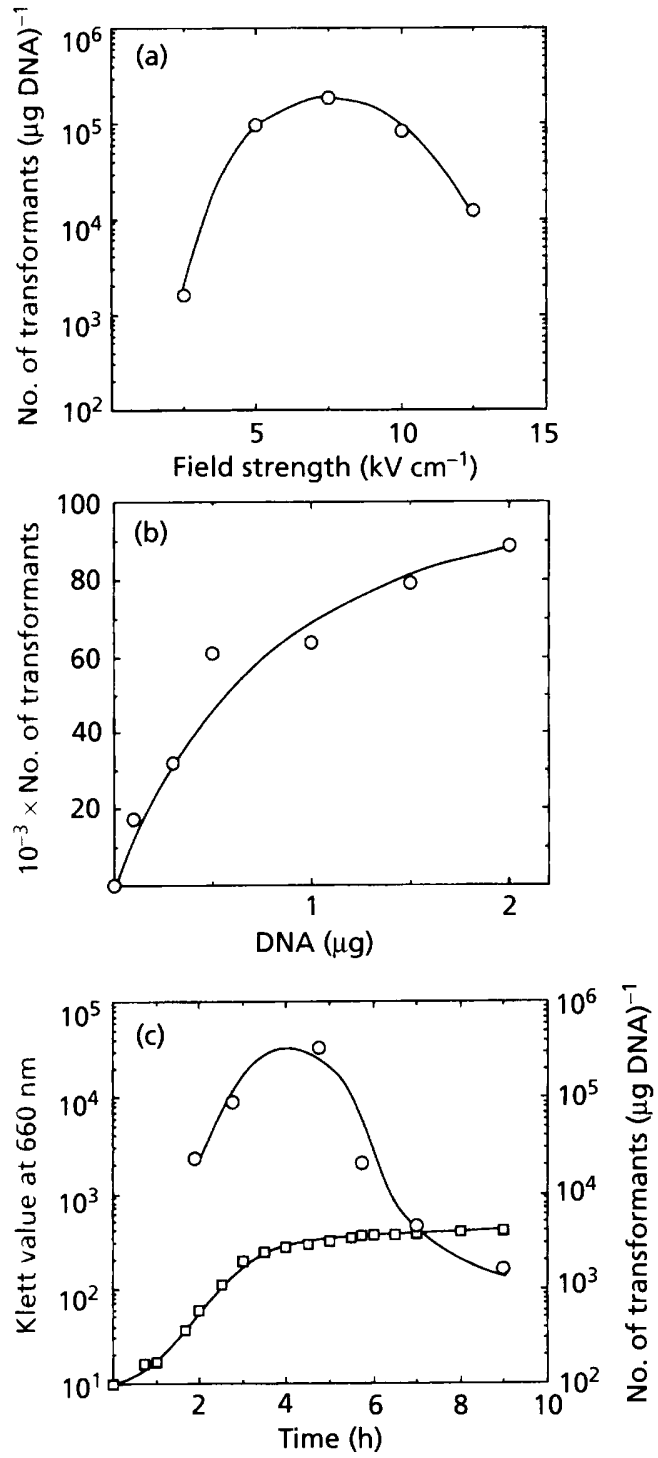

Fig. 6. Effects of electric field strength (a), amount of plasmid DNA (b), and growth phase (c) on the efficiency of transformation. Osmotically shocked VIK2 cells were used in all experiments, and electroporation was carried out under the following conditions: (a) Klett value of the culture when harvested was 150 and the amount of pSU21 DNA was $0.5 \mu \mathrm{g}$; (b) Klett value was 150 and the electric field strength was set at $5.0 \mathrm{kV} \mathrm{cm}{ }^{1 ;}$ (c) $0.1 \mu \mathrm{g}$ pSU21 was used and the electric field strength was set at $7.5 \mathrm{kV} \mathrm{cm}^{-1}$. $\square$, Klett value $(660 \mathrm{~nm})$ of the culture; $\mathrm{C}$, number of $\mathrm{Cm}^{r}$ transformants per $\mu \mathrm{g}$ DNA.

very similar to those obtained without osmotic shock (Figs 1-3).

With this reasonably high efficiency of transformation (about $10^{5}$ transformants per $\mu \mathrm{g}$ DNA input) obtained, we attempted to transform VIK2 cells with plasmids pIO1 $\left(\mathrm{Cm}^{\mathrm{r}} \mathrm{Km}^{r}\right)$, which consists of pSU21 and the $\mathrm{Km}^{\mathrm{r}}$ gene cassette from pUC4K, and pACYC184 $\left(\mathrm{Cm}^{\mathrm{r}} \mathrm{Tc}^{\mathrm{r}}\right.$ ) (data not shown). All 50 colonies tested on the plates containing $100 \mu \mathrm{g}$ kanamycin $\mathrm{ml}^{-1}$ after electroporation with pIO1 were also found to be resistant to $2.5 \mu \mathrm{g}$ chloramphenicol $\mathrm{ml}^{-1}$. Similarly, when pACYC184 was introduced, 50 out of $50 \mathrm{Tc}^{\mathrm{r}}$ transformants were found to be $\mathrm{Cm}^{\mathrm{r}}$. Thus, these P15A plasmids as well as pSU38 and pSU41 can be maintained in the $V$. alginolyticus cells and kanamycin $\left(100 \mu \mathrm{g} \mathrm{ml}^{-1}\right)$ and tetracycline $\left(1.25 \mu \mathrm{g} \mathrm{ml}^{-1}\right)$ can be used for selection of transformants.

\section{DISCUSSION}

In this study we established a reliable procedure for electroporation in $V$. alginolyticus. When a plasmid with the P15A replicon and the $\mathrm{Cm}^{\mathrm{r}}$ gene is used as a vector, about $10^{5}$ transformants per $\mu \mathrm{g}$ of input DNA are reproducibly obtained under optimal conditions. Major differences from the standard procedure for $E$. coli (Dower et al., 1988) are as follows. (i) Cells are harvested at early stationary phase rather than early-exponential phase. (ii) Cells are subjected to relatively mild osmotic shock before extensive washing. (iii) Cells are washed in the presence of 5-10 $\mathrm{mM} \mathrm{MgSO}_{4}$. (iv) Electroporation is performed using a pulse with an electric field strength of between $5 \cdot 0$ and $7.5 \mathrm{kV} \mathrm{cm}^{-1}$.

We found that the culture medium of $V$. alginolyticus cells contains considerable DNA-degrading activity, whereas that of E. coli does not. The $V$. alginolyticus DNase can degrade covalently closed circular forms of plasmid DNA and is active even at $0^{\circ} \mathrm{C}$. Permeabilization of the outer membrane by osmotic shock was carried out to remove the DNase which otherwise would remain in the periplasmic space even after thorough washing of the cells. This manipulation resulted in about a 10 -fold increase in the efficiency of transformation.

$V$. alginolyticus cells are easily lysed when exposed to low ionic strength; the presence of magnesium ions prevents this cell lysis, probably by stabilizing the outer membrane (Unemoto et al., 1973; Unemoto \& MacLeod, 1975). Therefore 5-10 $\mathrm{mM} \mathrm{MgSO}_{4}$ was used throughout the washing process. The presence of higher concentrations (up to $50 \mathrm{mM}$ ) did not significantly increase the efficiency of transformation (data not shown).

It was found that plasmids which have the P15A replicon can be stably maintained in $V$. alginolyticus cells even in the absence of selective pressure. Chloramphenicol $\left(1.25 \mu \mathrm{g} \mathrm{ml}^{-1}\right)$, kanamycin $\left(200 \mu \mathrm{g} \mathrm{ml}^{-1}\right)$ and tetracycline $\left(1.25 \mu \mathrm{g} \mathrm{ml}^{-1}\right)$ can be used for selection of transformants. However, in the case of pHSG398, a $\mathrm{Cm}^{\mathrm{r}}$-carrying plasmid containing the replicon of $\mathrm{pMB1}$, the original form of DNA from the $\mathrm{Cm}^{r}$ transformants was not recovered, although Hamashima et al. (1990) reported that the same plasmid can be maintained in the Vibrio cells. This discrepancy might be due to the difference in the recipient strains. We wished, however, to use strain 138-2 and its derivatives since 138-2 has been well characterized in terms of the bioenergetics of the respiration-coupled sodium pump (Tokuda, 1989; Unemoto \& Hayashi, 1989) and the flagellar motors (Tokuda et al., 1988; Atsumi et al., 1992).

The efficiency of transformation of $V$. alginolyticus under the optimal conditions in this study is still lower than that of $E$. coli, but is not too low for routine use in experiments 
such as shot-gun cloning. We have already isolated mutants defective in the polar and lateral flagella ( Pof $^{-}$ $\mathrm{Laf}^{-}$) from the wild-type strain 138-2 (Y. Maekawa, I. Kawagishi, Y. Imae \& M. Homma, unpublished). Since these mutants cannot make swarm colonies on $0.3 \%$ agar plate, we expect to clone genes responsible for the formation of polar or lateral flagella by introducing libraries (with pSU21 as vector) of $V$. alginolyticus chromosome DNA into the Pof ${ }^{-} \mathrm{Laf}^{-}$strains and by selecting transformants which recover the ability to form swarm colonies.

\section{ACKNOWLEDGEMENTS}

We thank Drs B. Bartolomé of Universidad de Cantabria, Spain, and J. Messing of the State University of New Jersey for providing us with plasmids. We are especially grateful to $\mathrm{Dr}$ R. M. Macnab of Yale University for critically reading the manuscript. This work was supported in parts by Grants-in-Aid for Scientific Research to I.K. from the Ishida Foundation, and from the Ministry of Education, Science, and Culture of Japan.

\section{REFERENCES}

Allen, R. D. \& Baumann, P. (1971). Structure and arrangement of Alagella in species of the genus Beneckea and Photobacterium fischeri. $J$ Bacteriol 107, 295--302.

Allison, C. \& Hughes, C. (1991). Bacterial swarming: an example of prokaryotic differentiation and multicellular behaviour. Sci Prog 75, 403-422.

Atsumi, T., McCarter, L. \& Imae, Y. (1992). Polar and late:al flagellar motors of marine $L$ ibrio are driven by different ion-motive forces. Nature 355, 182-184.

Bartolomé, B., Jubete, Y., Martinez, E. \& Cruz, F. D. (1991). Construction and properties of a family of pACYC184-derived cloning vectors compatible with pBR322 and its derivatives. Gene 102, 75-78.

Belas, R., Mileham, A., Simon, M. \& Silverman, M. (1984). Transposon mutagenesis of marine Vibrio spp. J Bacteriol 158, 890-896.

Belas, R., Mileham, A., Cohn, D., Hilmen, M., Simon, M. \& Silverman, M. (1986). Bacterial bioluminescence: isolation and expression of the luciferase genes from Librio barveyi. Science $\mathbf{2 1 8}$, 791-793.

Bolivar, F., Rodriguez, R. L., Greene, P. J., Betlach, $M_{n}$ C., Heyneker, H. L., Boyer, H. W., Crosa, J. H. \& Falkow, S. (1977). Construction and characterization of new cloning vehicles. Il. A multipurpose cloning system. Gene 2, 95-113.

Chang, A. C. Y. \& Cohen, S. N. (1978). Construction and characterization of amplifiable multicopy DNA cloning vehicles derived from the P15A cryptic miniplasmid. J Bacteriol 134, 1141-1156.

Dower, W. J., Miller, J. F. \& Ragsdale, C. W. (1988). High efficiency transformation of E. coli by high voltage electroporation. Nicleic Acids Res 16, 6127-6145.

Focareta, T. \& Manning, P. A. (1987). Extracellular proteiris of Vibrio cholerae: molecular cloning, nucleotide sequence and characterization of the deoxyribonuclease (DNase) together with its periplasmic localization in Eschericbia coli. Gene 53, 31-40.

Grant, S. G., Jessee, J., Bloom, F. R. \& Hanahan, D. (1990). Differential plasmid rescue from transgenic mouse DNAs into Escherichia coli methylation-restriction mutants. Proc Natl Acad Sci US A 87, 4645-4649.

Hamashima, H., Nakao, T., Tamura, S. \& Arai, T. (1990). Genetic transformation of Vibrio parabaemolyticus, L'ibrio alginolyticus and Vibrio cholerae non-O1 with plasmid DNA by electroporation. Microbiol Immunol 34, 703-708.

Henrichsen, J. (1972). Bacterial surface translocation: a survey and a classification. Bacteriol Rev 36, 478-503.

Imae, Y. \& Atsumi, T. (1989). $\mathrm{Na}^{+}$-driven bacteria flagellar motors. $J$ Bioenerg Biomembr 21, 705-716.

Kaneko, T. \& Colwell, R. T. (1973). Ecology of I ibrio parabaemolyticus in Chesapeake Bay. J Bacteriol 113, 24-32.

Marcus, H., Ketley, J. M., Kaper, J. B. \& Holmes, R. H. (1990). Effects of DNase production, plasmid size, and restriction barriers on transformation of Vibrio cholerae by electroporation and osmotic shock. FEMS Microbiol Lett 68, 149-154.

McCarter, L. L. \& Silverman, M. (1987). Phosphate regulation of gene expression in Vibrio parabaemolyticus. $J$ Bacteriol 169, 3441-3449.

McCarter, L. \& Silverman, M. (1990). Surface-induced swarmer cell differentiation of Vibrio parabaemolyticus. Mol Microbiol 4, 1057-1062.

McCarter, L., Hilmen, M. \& Silverman, M. (1988). Flagellar dynamometer controls swarmer cell differentiation of Vibrio parabaemolyticus. Cell 54, 345-351.

Muramatsu, K. \& Matsumoto, H. (1991). Two generalized transducing phages in $V$. parahaemolyticus and $I$. alginolyticus. Microbiol Immunol 35, 1073-1084.

Neu, H. C. \& Heppel, L. A. (1965). The release of enzyme from Escherichia coli by osmotic shock and during the formation of spheroplasts. J Biol Chem 240, 3685-3692.

Newland, J. W., Green, B. A., Foulds, J. \& Holmes, R. K. (1985). Cloning of extracellular DNase and construction of a DNase negative strain of Vibrio cholerae. Infect Immun 47, 691-696.

Sambrook, J., Fritsch, E. F. \& Maniatis, T. (1987). Molecular Cloning: a Laboratory Manual, 2nd edn. Cold Spring Harbor, NY: Cold Spring Harbor Laboratory.

Shinoda, S. \& Okamoto, K. (1977). Formation and function of Vibrio parabaemolyticus lateral flagella.J Bacteriol 129, 1266-1271.

Silhavy, T. J., Berman, M. L. \& Enquist, L. W. (1984). Experiments with Gene Fusions. Cold Spring Harbor, NY: Cold Spring Harbor Laboratory.

Takeshita, S., Sato, M., Masahashi, W. \& Hashimoto-Gotoh, T. (1987). High-copy-number and low-copy-number plasmid vector for lac $Z \alpha$-complementation and chloramphenicol or kanamycin resistance selection. Gene 61, 63-74.

Tokuda, H. (1986). Sodium translocation by NADH oxidase of Vibrio alginolyticus: isolation and characterization of the sodium pump-defective mutants. Methods Enzymol 125, 520-530.

Tokuda, H. (1989). Respiratory $\mathrm{Na}^{+}$pump and $\mathrm{Na}^{+}$-dependent energetics in V'ibrio alginolyticus. J Bioenerg Biomembr 21, 693-704.

Tokudo, H. \& Unemoto, T. (1982). Characterization of the respiration-dependent $\mathrm{Na}^{+}$pump in the marine bacterium l'ibrio alginolyticus. J Biol Chem 257, $10007-10014$.

Tokuda, H., Nakamura, T. \& Unemoto, T. (1981). Potassium ion is required for the generation of $\mathrm{pH}$-dependent membrane potential and $\Delta \mathrm{pH}$ by the marine bacterium Vibrio alginolyticus. Biochemistry 20, 4198-4203.

Tokuda, H., Asano, M., Shimamura, Y., Unemoto, T., Sugiyama, S. \& Imae, Y. (1988). Roles of the respiratory $\mathrm{Na}^{+}$pump in bioenergetics of V'ibrio alginolyticus. J Biochem 103, 650-655.

Tsuchiya, T. \& Shinoda, S. (1985). Respiration-driven $\mathrm{Na}^{+}$pump and $\mathrm{Na}^{+}$circulation in V'ibrio parabaemolyticus. J Bacteriol 162, 794-798. 
Unemoto, T. \& Hayashi, M. (1989). Sodium-transport NADHquinone reductase of a marine Librio alginolyticus. J Bioenerg Biomembr 21, 649.662.

Unemoto, T. \& MacLeod, R. A. (1975). Capacity of the outer membrane of a gram-negative marine bacterium in the presence of cations to prevent lysis by Triton X-100. J Bacteriol 121, 800-806.

Unemoto, T., Tsuruoka, T. \& Hayashi, M. (1973). Role of $\mathrm{Na}^{+}$and $\mathrm{K}^{+}$in preventing lysis of a slightly halophilic Librio alginolyticus. Can J Nicrobiol 19, 563-571.

Vieira, J. \& Messing, J. (1982). The pUC plasmids, an M13mp7- derived system for insertion mutagenesis and sequencing with synthetic universal primers. Gene 19, 259-268.

Vieira, J. \& Messing, J. (1991). New pLC-derived cloning vectors with different selectable markers and DNA replicon origins. Gene 100, 189-194.

Yu, C., Lee, A. M., Bassler, B. L. \& Roseman, S. (1991). Chitin utilization by marine bacteria. J Biol Chem 266, 24260-24267.

Received 22 December 1993; revised 5 May 1994; accepted 13 May 1994. 